\title{
OPTIMASI SELULASE PADA ENZYME ASSISTED EXTRACTION LEMAK DARI Caulerpa lentillifera SEGAR MENGGUNAKAN RESPONSE SURFACE METHODOLOGY
}

\section{OPTIMIZATION OF CELLULASE ENZYME ASSISTED EXTRACTION OF LIPID FROM FRESH Caulerpa lentillifera USING RESPONSE SURFACE METHODOLOGY}

\author{
Ishmah Hanifah ${ }^{*}$, Fauzia Izzati $^{2}$, Siti Irma Rahmawati ${ }^{2}$, Joko Hermanianto ${ }^{1}$, \\ Puspo Edi Giriwono ${ }^{1}$, Yatri Hapsari ${ }^{2}$, Bustanussalam ${ }^{2}$, Fauzy Rahman ${ }^{2}$, \\ Eris Septiana $^{2}$, \& Partomuan Simanjuntak ${ }^{2}$ \\ ${ }^{1}$ Departemen Ilmu dan Teknologi Pangan, Fakultas Teknologi Pertanian, \\ IPB University, Bogor, 16002, Indonesia \\ ${ }^{2}$ Pusat Penelitian Bioteknologi, Lembaga Ilmu Pengetahuan Indonesia, Bogor, 16911, Indonesia \\ *E-mail: ishmahhanifah8@gmail.com
}

\begin{abstract}
Caulerpa lentillifera is one of the most potential green seaweed to explored. It is abundantly available and cultivated in several region in Indonesia. Seaweed is well-known as a low lipid content but it is arranged by polyunsaturated fatty acid. Generally, organic solvent is used for lipid extraction. In an extraction method needs pre-treatment such as enzyme assisted extraction for degrading its cell wall and increasing solvent access to entry the cell. This research was designed to study the optimum condition of lipid enzyme assisted extraction process using cellulase from fresh green macroalga $C$. lentillifera. The optimization was carried out by Response Surface Methodology (RSM) using Central Composite Design (CCD) model with 15 runs. The aim of this study was to analyze the effect of some independent variables namely enzyme concentrations, hydrolysis temperatures, and hydrolysis times respectively to the dependent variables of lipid content and antioxidant activity. The optimum condition obtained from this experiment was $2 \%$ enzyme concentration, $30^{\circ} \mathrm{C}$ hydrolysis temperature, and $1 \mathrm{~h}$. The optimum condition could then be verified by making 2 or more replications of the chosen treatment approached the predicted result based on software Design Expert vers. 10 prediction. After methylation, extracted fatty acids were identified as palmitic acid and lauric acid using GC-MS. Extraction optimization enables to explore C. lentillifera's lipid based on influence factors.
\end{abstract}

Keywords: Caulerpa lentillifera, cellulase, enzyme assisted extraction, lipid, RSM

\begin{abstract}
ABSTRAK
Caulerpa lentillifera merupakan rumput laut hijau yang memiliki potensi besar namun kelimpahannya belum banyak dieksplorasi. Rumput laut tersebut tersebar pada beberapa wilayah perairan di Indonesia. Rumput laut diketahui memiliki kadar lemak yang rendah namun tersusun oleh poli asam lemak tidak jenuh. Ekstraksi lemak pada umumnya hanya menggunakan pelarut organik. Pada proses ekstraksi diperlukan perlakuan awal seperti enzyme assisted extraction untuk mendegradasi dinding sel dan meningkatkan akses pelarut masuk ke dalam sel. Penelitian dirancang untuk mengetahui kondisi optimum proses enzyme assisted extraction lemak rumput laut hijau segar $C$. lentillifera dengan menggunakan enzim selulase. Proses optimasi dilakukan menggunakan Response Surface Methodology (RSM) model Central Composite Design dengan 15 perlakuan. Perlakuan didapatkan untuk mengetahui pengaruh variabel bebas, diantaranya konsentrasi enzim, suhu hidrolisis, dan waktu hidrolisis terhadap variabel terikat yaitu jumlah ekstrak lemak dan aktivitas antioksidan. Hasil penelitian didapatkan model 2FI dan Linier berturut-turut untuk variabel terikat jumlah lemak dan aktivitas antioksidan. Kondisi optimum yang diperoleh yaitu konsentrasi enzim sebesar $2 \%$, suhu hidrolisis sebesar $30{ }^{\circ} \mathrm{C}$, dan waktu hidrolisis selama 1 jam. Kondisi optimum tersebut kemudian dapat diverifikasi dengan diberikan perlakuan terpilih sebanyak 2 kali ulangan atau lebih hingga mendekati hasil prediksi. Asam lemak yang diperoleh setelah metilasi dan identifikasi dengan GC-MS yaitu asam palmitat dan asam laurat. Optimasi proses ekstraksi lemak memungkinkan potensi pemanfaatan lemak dari rumput laut segar $C$. lentillifera berdasarkan faktor yang memengaruhi.
\end{abstract}

Kata kunci: Caulerpa lentillifera, enzyme assisted extraction, lemak, selulase, RSM 


\section{PENDAHULUAN}

Rumput laut di Indonesia merupakan salah satu komoditas unggulan perikanan budi daya yang dapat diperbaharui. Potensinya tersebar di 23 provinsi di Indonesia (Perpres, 2019). Ragam sumber daya rumput laut terdiri dari 555 jenis, namun produksi dan perdagangan rumput laut didominasi oleh rumput laut merah dan cokelat. Potensi jenis rumput laut hijau yang dapat dikembangkan salah satunya adalah genus Caulerpa sp. dengan spesies Caulerpa lentillifera (KKP, 2019). Rumput laut $C$. lentillifera tersebar di beberapa wilayah Indonesia yaitu di Kecamatan Kei-Kecil Barat, Kabupaten Maluku Tenggara (Dangeubun \& Kadmaer, 2018), perairan Pulau Beralas Bakau, Kabupaten Bintan (Prakoso et al., 2019), dan Pulau Bunguran, Natuna (Razai et al., 2019). Rumput laut juga dibudidayakan di Balai Besar Perikanan Budidaya Air Payau (BBPBAB) Jepara dan Balai Perikanan Budidaya Air Payau (BPBAP) Takalar, Sulawesi (Dahlia et al., 2015), dikenal dengan nama lokal "lawi-lawi" di Sulawesi dan "latoh" di Jawa (Supriadi et al., 2016). C. lentillifera mengandung protein, asam lemak tak jenuh, karbohidrat, serta kaya akan komponen bioaktif (Sanjeewa et al., 2018). Iklim dan kondisi laut dapat menyebabkan perbedaan komposisi nutrisi pada rumput laut. $C$. lentillifera pada kondisi segar memiliki kadar air sebesar 98,28\%, kadar protein $0,53 \%$, kadar lemak 0,09\%, serat kasar 0,17\% dan kadar karbohidrat 3,67\% (Nguyen et al., 2011). Beberapa rumput laut memiliki kandungan polyunsaturated fatty acid (PUFA) pada kadar lemaknya. Namun kelimpahan rumput laut di Indonesia belum banyak di eksplorasi. Kandungan dan jenis asam lemak pada $C$. lentillifera dapat berbeda bergantung pada habitatnya (Ginneken et al., 2011).

Ekstraksi lemak umumnya menggunakan pelarut organik misalnya heksana dan kloroform. Protokol dan pelarut yang berbeda akan menentukan kuantitas lemak yang terekstrak. Selain itu, tipe sampel dan keberadaan dinding sel juga dapat memengaruhi jumlah lemak yang terekstrak. Ekstraksi dengan pelarut organik yang menghasilkan lemak paling banyak yaitu pada metode bligh and dyer diikuti dengan metode folch (Fiset et al., 2017). Rumput laut mensintesis berbagai jenis polisakarida sebagai komponen struktural dinding sel atau cadangan energi. Dinding sel rumput laut terdiri dari jaringan biopolimer yang sangat terintegrasi (Synytsya et al., 2015). Dinding sel rumput laut secara umum tersusun oleh kerangka dengan bahan selulosa (Deslandes et al., 2016). Sejumlah lemak terperangkap di dalam dinding sel, sehingga ekstraksi hanya dengan pelarut akan menghasilkan jumlah lemak yang sedikit. Pada proses ekstraksi diperlukan perlakuan awal untuk mendisrupsi atau mendegradasi sel terlebih dahulu. Perlakuan tersebut dapat meningkatkan akses pelarut untuk mengekstrak lemak di dalamnya. Beberapa contoh perlakuan awal sebelum ekstraksi adalah pengeringan, cairan superkritis, microwave, dan enzimatis. Proses enzimatis merupakan proses biokimia yang membutuhkan energi yang sedikit dibanding proses mekanis. Dinding sel dapat dilemahkan dan dihilangkan dengan degradasi selulosa (Lin et al., 2018).

Proses ekstraksi merupakan tahapan yang penting untuk mengisolasi berbagai komponen atau senyawa bioaktif dari bahan tanaman. Keberadaan berbagai polisakarida dalam jumlah besar di dinding sel dapat mengurangi efisiensi ekstraksi. Degradasi dari dinding sel dengan struktur polisakarida merupakan langkah dasar dalam pelepasan komponen aktif atau komponen lainnya. Teknik ekstraksi telah dikembangkan untuk meningkatkan efisiensi ekstraksi yaitu dengan menggunakan bantuan enzim sebagai pendegradasi dinding sel (Wijesinghe \& Jeon, 2012). Teknik ekstraksi dengan bantuan enzim tersebut dinamakan dengan enzyme assisted extraction. Pada teknik ini, enzim yang biasa digunakan adalah karbohidrase 
seperti selulase (Reddy \& Majumder, 2014). Optimasi ekstraksi pada lemak dilakukan untuk mengurangi biaya dan efisiensi waktu penelitian. Optimasi ekstraksi dengan pemodelan statistik dan matematis melalui analisis proses dapat mengefisiensi waktu dan tenaga untuk melakukan total percobaan. Salah satunya yaitu dengan menggunakan response surface methodology (RSM) (Mubarak et al., 2016). Metode RSM didasarkan pada kecocokan model statistik untuk mengukur data yang diperoleh sehubungan dengan desain eksperimen. Metode ini terbukti untuk meningkatkan dan mengoptimalkan proses biokimia untuk mengekstraksi jumlah maksimum senyawa tertentu. Model percobaan pada RSM yang umum digunakan adalah model central composite design (CCD). Optimasi dengan CCD dapat memungkinkan penyaringan berbagai parameter serta peran setiap faktor (Anne-sophie et al., 2016). Penelitian ini bertujuan untuk mengoptimasi proses ekstraksi lemak dari $C$. lentillifera yang berasal dari BBPBAP Jepara dengan bantuan enzim selulase. Pada perlakuan optimal tersebut, asam lemak diidentifikasi menggunakan GC-MS dan diharapkan dapat meningkatkan nilai tambah dari rumput laut hijau $C$. lentillifera.

\section{METODE PENELITIAN}

Penelitian dilakukan pada bulan Agustus-November 2019 di Laboratorium Kimia Bahan Alam Pusat Penelitian Bioteknologi, Lembaga Ilmu Pengetahuan Indonesia, Bogor, Indonesia. Bahan yang digunakan pada penelitian ini adalah rumput laut $C$. lentillifera dari BBPBAP Jepara, enzim selulase novozymes viscozyme cassava $\mathrm{CL}$, asam asetat, diklorometan, 2,2-Azinobis (3-Etilbenzotiazolin)-6-Asam Sulfonat (ABTS), kalium persulfat, etanol, heksana, $\mathrm{KOH}$, metanol, akuades, $\mathrm{NaOH}$, DNS (3,5-Dinitrosalicylic Acid), fenol, Na2S2O5, Na-K-Tartarat, buffer sitrat pH 5 dan standar glukosa.

\subsection{Kinetika Enzim terhadap Substrat}

Aktivitas hidrolisis pada substrat rumput laut dapat diamati dengan menganalisis kinetika enzim yang digunakan. Metode yang digunakan adalah metode DNS. Pembuatan pereaksi DNS dilakukan dengan melarutkan $1 \mathrm{~g} \mathrm{NaOH}$ di dalam $25 \mathrm{~mL}$ akuades, kemudian tambahkan DNS sebanyak 1 g. Fenol sebanyak 0,02 g dilelehkan pada suhu $50{ }^{\circ} \mathrm{C}$. Fenol dicampurkan ke dalam larutan $\mathrm{NaOH}-\mathrm{DNS}$ (Larutan A). Sebanyak 0,05 g Na $2 \mathrm{~S}_{2} \mathrm{O}_{5}$ dan 20 g Na-K-Tartarat dilarutkan dalam $25 \mathrm{~mL}$ akuades (Larutan B). Larutan A dan Larutan B kemudian dicampur dan ditepatkan hingga $100 \mathrm{~mL}$ dengan akuades. Larutan standar yang digunakan adalah larutan glukosa dengan serial konsentrasi $0,05 \mathrm{~g} / \mathrm{L}, 0,1 \mathrm{~g} / \mathrm{L}$, $0,15 \mathrm{~g} / \mathrm{L}, 0,2 \mathrm{~g} / \mathrm{L}, 0,25 \mathrm{~g} / \mathrm{L}$, dan $0,3 \mathrm{~g} / \mathrm{L}$.

Larutan standar diambil sebanyak 0,2 $\mathrm{mL}$ dan ditambah pereaksi DNS sebanyak 0,6 $\mathrm{mL}$ kemudian divorteks. Larutan dididihkan selama 10 menit hingga berubah warna menjadi kecokelatan, setelah itu absorbansinya diukur dengan spektrofotometer UV-Vis pada panjang gelombang $540 \mathrm{~nm}$. Larutan sampel di dalam buffer sitrat disiapkan dengan serial konsentrasi $0 \mathrm{~g} / \mathrm{L}, 2 \mathrm{~g} / \mathrm{L}, 4 \mathrm{~g} / \mathrm{L}, 6 \mathrm{~g} / \mathrm{L}, 10 \mathrm{~g} / \mathrm{L}$, $20 \mathrm{~g} / \mathrm{L}, 30 \mathrm{~g} / \mathrm{L}, 40 \mathrm{~g} / \mathrm{L}$ dan $50 \mathrm{~g} / \mathrm{L}$, kemudian enzim ditambahkan sebanyak 3,4 g/L. Total volume larutan adalah sebanyak $5 \mathrm{~mL}$ selanjutnya divorteks. Setelah divorteks, larutan sampel diinkubasi pada $\mathrm{pH} 5$ dan suhu $50{ }^{\circ} \mathrm{C}$ selama 40 menit. Enzim diinaktivasi pada suhu $85{ }^{\circ} \mathrm{C}$ selama 10 menit. Larutan sampel diambil sebanyak $1 \mathrm{~mL}$ dan ditambah pereaksi DNS sebanyak $3 \mathrm{~mL}$, setelah itu ukur absorbansi larutan pada panjang gelombang $540 \mathrm{~nm}$. (Saropah et al., 2012; Guerra, 2017).

\subsection{Enzyme Assisted Extraction}

Sampel rumput laut $C$. lentillifera dihancurkan dan ditimbang sebanyak $100 \mathrm{~g}$ berat basah kemudian ditempatkan di dalam tabung erlenmeyer $250 \mathrm{~mL}$. Asam asetat ditambahkan hingga mencapai $\mathrm{pH}$ optimum 
enzim yaitu $\mathrm{pH}$ 5. Setelah mencapai $\mathrm{pH}$ optimum, enzim ditambahkan sesuai konsentrasi yang telah ditentukan. Aktivasi enzim dilakukan dengan pemanasan dalam waterbath pada suhu yang telah ditentukan selama 30 menit. Kemudian sampel digoyangkan menggunakan shaker dengan kecepatan $30 \mathrm{rpm}$ selama waktu yang telah ditentukan. Inaktivasi enzim dilakukan untuk menghentikan reaksi dengan menambahkan asam asetat hingga mencapai $\mathrm{pH} 3$. Selanjutnya, pelarut ditambahkan ke dalam corong pisah dengan perbandingan 1:1 (pelarut: sampel v/w). Setelah pengocokan dan pendiaman selama 2-5 menit, terbentuk 3 fase lapisan (aqueous, cell debris, dan pelarut organik). Fase organik diambil dan dimasukkan ke dalam vial, kemudian pelarut diuapkan. Hasil ekstraksi ditimbang untuk menghitung jumlah lemak yang terekstrak (Liang et al., 2012; Yingyao et al., 2008).

\subsection{Aktivitas Antioksidan ABTS}

Sebanyak 19,2 mg ABTS dilarutkan dalam $5 \mathrm{~mL}$ akuades dan dimasukkan ke dalam erlenmeyer $50 \mathrm{~mL}$ yang terbungkus alumunium foil. Sebanyak $88 \mu \mathrm{L}$ kalium persulfat (189 mg Kalium persulfat dalam 5 $\mathrm{mL}$ akuades) ditambahkan. Campuran kemudian disimpan selama 16 jam dalam ruangan gelap pada suhu ruang. Sebanyak 5 $\mathrm{mL}$ campuran dimasukkan ke dalam erlenmeyer $200 \mathrm{~mL}$ yang terbungkus alumunium foil untuk dilarutkan dengan etanol sebanyak $155 \mathrm{~mL}$. Larutan blanko adalah campuran etanol dan ekstrak (1:1 v/v), larutan zeroing adalah etanol dan ABTS (1:1 $\mathrm{v} / \mathrm{v}$ ), sedangkan larutan sampel berisi sampel dengan konsentrasi sebesar 100 ppm. Inkubasi dilakukan selama 6 menit pada suhu $37{ }^{\circ} \mathrm{C}$ di waterbath. Pengukuran serapan dilakukan pada panjang gelombang $734 \mathrm{~nm}$ dengan spektrofotometer UV-Vis itachi U-3900H (Fitriana et al., 2015). Aktivitas penghambatan radikal dapat dihitung menggunakan persamaan (1):

$$
\begin{aligned}
& \text { Penghambatan }(\%)= \\
& \frac{(\text { Abs blanko-Abs sampel })}{\text { Abs blanko }} \times 100 \%
\end{aligned}
$$

Informasi: $A b s$ adalah absorbansi. Absorbansi yang digunakan adalah absorbansi sampel dan absorbansi blanko (tanpa sampel).

\subsection{Pembuatan Fatty Acid Methyl Ester (FAME)}

Asam lemak dikonversi menjadi FAME dengan menambahkan $2 \mathrm{~mL}$ $\mathrm{KOH}-\mathrm{CH} 3 \mathrm{OH}(0,4 \mathrm{~mol} / \mathrm{L})$ dan dipanaskan pada suhu $40{ }^{\circ} \mathrm{C}$ selama 10 menit di waterbath. FAME diekstrak dengan menambahkan heksana sebanyak $2 \mathrm{~mL}$. Campuran kemudian ditambah dengan $5 \mathrm{~mL}$ akuades dan divortex selama 15 detik. Bagian atas yang mengandung FAME kemudian diambil sebanyak $2 \mathrm{~mL}$ dan dimasukkan ke dalam vial. Selanjutnya, sampel dikeringkan sebelum dilakukan analisis dengan menggunakan GC-MS (Gao et al., 2013).

\subsection{Identifikasi Asam Lemak dengan GC-MS}

Lemak yang sudah ditransmetilasi menjadi FAME kemudian dianalisis menggunakan GC/MS-QP2010 Ultra Kolom

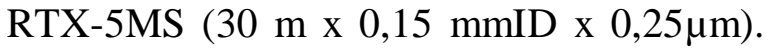
Adapun keterangan alat meliputi mode injeksi yaitu splitless dengan suhu $250{ }^{\circ} \mathrm{C}$, gas pembawa berupa helium dengan aliran konstan, mode kontrol aliran yaitu kecepatan linier, aliran kolom sebesar 2,40 mL/menit, kecepatan linier $51,7 \mathrm{~cm} /$ detik, dan suhu oven yaitu dari $40{ }^{\circ} \mathrm{C}$ menuju $250{ }^{\circ} \mathrm{C}$ dengan kenaikan $5{ }^{\circ} \mathrm{C} /$ menit (ditahan selama 20,55 menit).

\subsection{Rancangan Percobaan dan Analisis Data \\ Model yang digunakan adalah CCD dengan bantuan perangkat lunak Design}


Tabel 1. Kode perlakuan.

Table 1. Treatment code.

\begin{tabular}{lccccc}
\hline \multirow{2}{*}{ Independent variable } & \multicolumn{5}{c}{ Treatment code } \\
\cline { 2 - 6 } & -1.682 & -1 & 0 & 1 & 1.682 \\
\hline Enzyme concentration $(\%)$ & 0.977 & 2.0 & 3.5 & 5.0 & 6.023 \\
Temperature $\left({ }^{\circ} \mathrm{C}\right)$ & 19.773 & 30 & 45 & 60 & 70.227 \\
Time $(h)$ & 0.318 & 1 & 2 & 3 & 3.682 \\
\hline
\end{tabular}

Expert (DX) versi 10. Variabel bebas terdiri dari konsentrasi enzim, suhu hidrolisis, dan waktu hidrolisis dengan kode perlakuan pada Tabel 1. Pada variabel terikat terdiri dari rendemen lemak dan aktivitas antioksidan. Perlakuan optimal yang diperoleh diidentifikasi asam lemaknya dengan GC-MS. Variabel bebas dinotasikan sebagai $\mathrm{X}_{1}$ untuk konsentrasi enzim, $\mathrm{X}_{2}$ untuk suhu hidrolisis, dan $\mathrm{X}_{3}$ untuk waktu hidrolisis. Variabel terikat dinotasikan sebagai $Y_{1}$ untuk jumlah lemak dan $Y_{2}$ sebagai aktivitas antioksidan. Rentang variabel bebas didapatkan dari studi pustaka dan penelitian pendahuluan. Jumlah titik percobaan ditentukan dengan rumus $2^{\mathrm{k}}+2 \mathrm{k}$ + centre point. Notasi $k$ melambangkan faktor percobaaan, sedangkan pada $2^{\mathrm{k}}$ menunjukkan uji faktorial, $2 k$ menunjukkan uji aksial, dan $\mathrm{n}_{\mathrm{c}}$ menunjukkan uji titik pusat. Banyaknya perlakuan pada model CCD yaitu $2^{3}+(2 \times 3)+1=15$ titik percobaan (Tabel 2).

Variabel terikat $(\mathrm{Y})$ yang didapatkan kemudian dianalisis menggunakan ANOVA. Dari pengolahan data menggunakan Design Expert versi 10, didapatkan model linier yang diuji signifikansinya ( $p$-value) dan kesesuaian model regresi (lack of fit). Hubungan antara variabel terikat $(\mathrm{Y})$ dari hasil pengamatan dan faktor-faktor (X) pada desain eksperimen ini dapat dirumuskan menjadi 2 yaitu model 2FI (two factor interaction) dan Linear berdasarkan saran dari perangkat lunak.

\section{HASIL DAN PEMBAHASAN}

\subsection{Kinetika Enzim terhadap Substrat Rumput Laut}

Aktivitas enzim memiliki unit yang menunjukkan banyaknya enzim yang menghasilkan $1 \mu \mathrm{mol}$ glukosa per menit $(\mathrm{U} / \mathrm{mL})$. Aktivitas enzim $(\mathrm{U} / \mathrm{mL})$ dihitung dengan kadar glukosa, faktor pengenceran dibagi dengan bobot molekul glukosa dan waktu inkubasi (Yogyaswari et al., 2016). Aktivitas enzim (U/mL) yang dihasilkan dari reaksi katalitik enzim yaitu 1,98 U/mL sampai 4,14 U/mL. Konsentrasi glukosa yang dihasilkan dari reaksi hidrolisis tersebut yaitu $0,049 \mathrm{~g} / \mathrm{L}-0,101 \mathrm{~g} / \mathrm{L}$. Reaksi katalitik enzim ditunjukkan dalam bentuk kinetika Michaelis-Menten yang dicirikan oleh hubungan kecepatan reaksi (velocity) dan konsentrasi substrat ([S]) (Lone et al., 2014). Konsentrasi substrat (g/L) kemudian diplotkan dengan kecepatan reaksi ( $\mu$ mol/menit) untuk membentuk kurva. Perhitungan kecepatan reaksi menjadi bentuk glukosa dengan melibatkan massa molekul relatif $(\mathrm{Mr})$ glukosa yaitu sebesar 180 (Haryanto et al., 2018). Kecepatan reaksi yang dihasilkan yaitu $0 \mu \mathrm{mol} / \mathrm{menit}$ $-14,1 \mu \mathrm{mol} / \mathrm{menit}$ (Gambar 1).

Persamaan Michaelis-Menten kemudian ditransformasi menjadi pemetaan kebalikan ganda yang menghasilkan persamaan Lineweaver-Burk (Puspitasari et al., 2019). Kurva Lineweaver-burk digunakan untuk menemukan kinetika enzim seperti $\mathrm{K}_{\mathrm{m}}$ dan $\mathrm{V}_{\text {maks. }}$ Kurva tersebut diperoleh dengan menghubungkan $1 /[\mathrm{S}]$ pada sumbu $\mathrm{x}$ dengan $1 / \mathrm{v}$ pada sumbu $\mathrm{y}$ (double reciprocal plot) (Lone et al., 2014). Penentuan reaksi laju maksimum $\left(\mathrm{V}_{\text {maks }}\right)$ dan konstanta Michaelis-Menten $\left(\mathrm{K}_{\mathrm{m}}\right)$ 


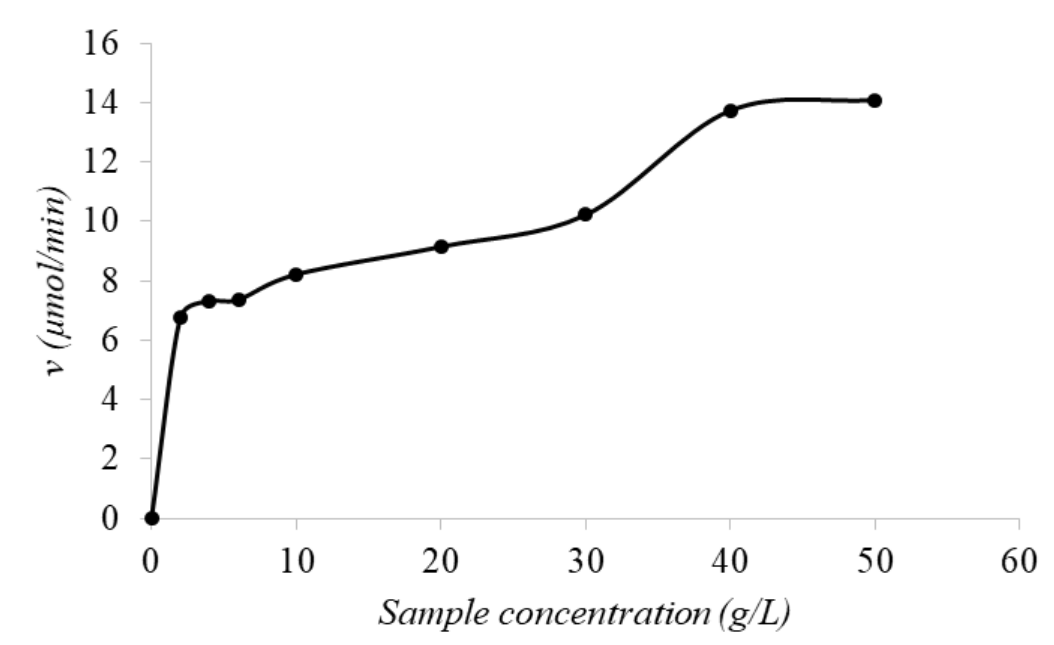

Gambar 1. Kurva Michaelis-Menten.

Figure 1. Michaelis-Menten Curve.

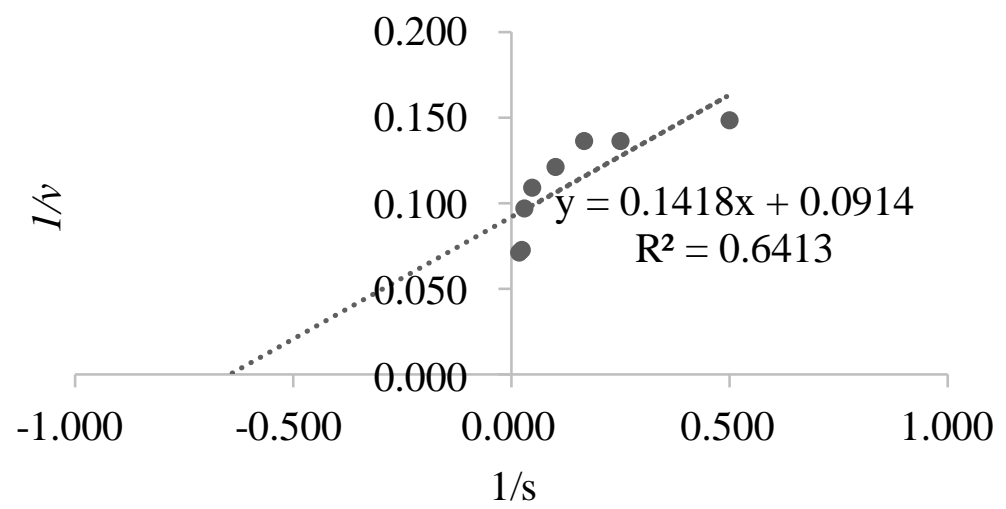

Gambar 2. Kurva Lineweaver-Burk.

Figure 2. Lineweaver-Burk Curve.

penting untuk mengetahui karakteristik enzim (Maftukhah \& Abdullah, 2018). Persamaan linear yang dihasilkan yaitu $\mathrm{y}=$ $0,1418 \mathrm{x}+0,0914$ dengan koefisien determinasi 0,6413 (Gambar 2). Nilai a pada persamaan tersebut menujukkan $\mathrm{K}_{\mathrm{m}} / \mathrm{V}_{\text {maks, }}$, sedangkan nilai $\mathrm{b}$ menunjukkan $1 / \mathrm{V}_{\text {maks }}$, sehingga nilai $\mathrm{K}_{\mathrm{m}}$ dan $\mathrm{V}_{\text {maks }}$ yang diperoleh berturut-turut adalah 1,55 $\mathrm{g} / \mathrm{L}$ dan 10,94 $\mu \mathrm{mol} / \mathrm{menit}$.

Nilai $\mathrm{V}_{\text {maks }}$ mengindikasikan tingkat kejenuhan enzim terhadap substrat, sedangkan $\mathrm{K}_{\mathrm{m}}$ mengindikasikan efisiensi katalis enzim yang didefinisikan sebagai konsentrasi substrat pada saat kecepatan katalitik enzim mencapai setengah dari kecepatan maksimumnya (Maftukhah \&
Abdullah, 2018). Semakin kecil nilai $K_{m}$ maka pengikatan enzim terhadap substrat semakin besar (Lone et al., 2014). Nilai $\mathrm{V}_{\text {maks }}$ ( $\mu \mathrm{mol} /$ menit) menunjukkan bahwa sebanyak 3,4 g/L enzim yang ditambahkan ke dalam substrat dapat mengubah produk sebesar 10,94 $\mu \mathrm{mol}$ per menit. Nilai $\mathrm{K}_{\mathrm{m}}$ yang dihasilkan kecil sehingga dapat dinyatakan pengikatan enzim terhadap substrat cukup besar. Menurut Maftukhah \& Abdullah (2018), nilai $K_{m}$ sangat bervariasi tergantung pada jenis substrat, keadaan lingkungan dan kekuatan ion. Enzim yang diekstrak dari sumber yang berbeda juga akan memiliki sifat yang berbeda, terutama respons enzim terhadap kondisi lingkungan, seperti suhu dan $\mathrm{pH}$. 


\subsection{Variabel Terikat pada Desain Percobaan}

Sampel yang digunakan adalah rumput laut segar C. lentillifera (Gambar 3). Bentuk rumput laut tersebut menyerupai anggur dan berwarna hijau. Sampel perlu dihancurkan terlebih dahulu menggunakan blender untuk selanjutnya diberi perlakuan sesuai desain percobaan CCD.

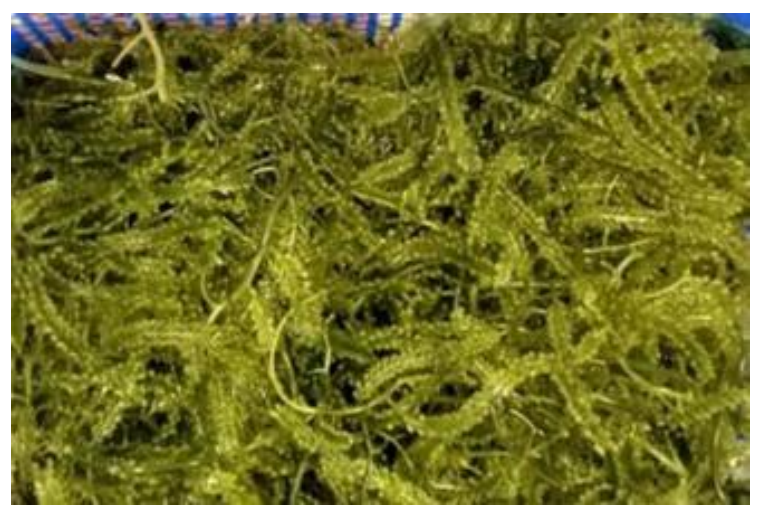

Gambar 3. Rumput laut segar $C$. lentillifera.

Figure 3. Fresh seaweed of C. lentillifera.

Pada desain percobaan CCD, terdapat titik pusat (titik merah dengan koordinat $0,0,0)$ yang terletak ditengah kubus digunakan untuk mendeteksi kelengkungan dalam variabel terikat. Titik aksial (enam titik biru terletak pada jarak $\alpha$ dari titik pusat) digunakan untuk memperkirakan koefisien suku kuadrat, sedangkan titik faktorial (delapan titik abu-abu terletak di sudut kubus) digunakan untuk memperkirakan koefisien dari suku-suku linier dan interaksi dua arah. Pada pengujian empat atau lebih faktor dalam percobaan Gambar 2 harus diperluas menjadi dimensi keempat atau lebih (Dutka et al., 2015).

Aspek penting pada CCD adalah lima tingkat faktor yang dipertimbangkan saat membangun desain yaitu $-\alpha,-1,0,+1$, dan $+\alpha$. Nilai $\alpha$ tergantung pada jumlah variabel. Pada jumlah variabel 2, 3, dan 4 memiliki nilai 1,41, 1,68, dan 2,00 (Ranade \& Thiagarajan, 2017). Jumlah percobaan yang dilakukan dalam CCD ditentukan oleh rumus berikut ketika desain faktorial adalah full: $\mathrm{N}=2^{\mathrm{k}}+2 \mathrm{k}+\mathrm{N}_{0}$. Apabila jumlah faktor bertambah, disarankan untuk membatasi jumlah percobaan (Ait-Amir et al., 2015). Berdasarkan Tabel 2, dengan jumlah faktor sebanyak 3, maka jumlah perlakuan yang digunakan adalah 15 dengan 1 titik pusat.

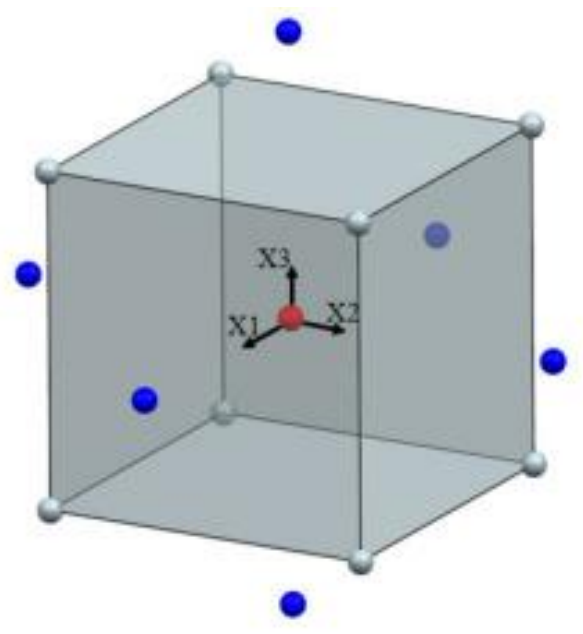

Gambar 4. Visualisasi CCD tipe asli yang dapat diputar untuk tiga faktor (Dutka et al., 2015).

Figure 4. Visualization of original type rotatable CCD for three factors (Dutka et al., 2015).

Tabel 2. Jumlah uji coba di CCD (Air-Amir et al., 2015).

Table 2. Number of trials in CCD (Air-Amir et al., 2015).

\begin{tabular}{ccc}
\hline $\begin{array}{c}\text { Number } \\
\text { offactors }\end{array}$ & $\begin{array}{c}\text { Number of } \\
\text { coefficient to } \\
\text { estimate }\end{array}$ & $\begin{array}{c}\text { Number of } \\
\text { trials }\end{array}$ \\
\hline 2 & 6 & 9 \\
3 & 10 & 15 \\
4 & 15 & 25 \\
5 & 21 & 43 \\
6 & 28 & 77 \\
\hline
\end{tabular}

Setelah data dikumpulkan, model fitting dapat menyatakan bahwa tidak semua parameter model signifikan (Iwundu, 2018). Pada penelitian ini, sebanyak 15 perlakuan (run) telah dianalisis dan menghasilkan variabel tetap (Y) yang terdiri dari jumlah lemak dan aktivitas antioksidan. Hasil pada tiap-tiap perlakuan dengan melibatkan 
Tabel 3. Data hasil percobaan.

Table 3. Experiment result.

\begin{tabular}{cccccc}
\hline Treatment & $\mathrm{X}_{1}\left({ }^{\circ} \mathrm{C}\right)$ & $\mathrm{X}_{2}(\%)$ & $\mathrm{X}_{3}(\mathrm{~h})$ & $\mathrm{Y}_{1}(\mathrm{mg} / 100 \mathrm{~g})$ & $\mathrm{Y}_{2}(\%)$ \\
\hline 1 & 30 & 2 & 1 & 9 & 28.60 \\
2 & 19.773 & 3.5 & 2 & 4.8 & 48.41 \\
3 & 70.227 & 3.5 & 2 & 7.2 & 41.40 \\
4 & 45 & 3.5 & 3.682 & 5.0 & 46.51 \\
5 & 60 & 5 & 3 & 9.2 & 57.44 \\
6 & 45 & 0.977 & 2 & 11 & 30.23 \\
7 & 45 & 6.023 & 2 & 3.6 & 21.63 \\
8 & 30 & 2 & 3 & 3.2 & 67.43 \\
9 & 60 & 2 & 3 & 5.4 & 29.30 \\
10 & 45 & 3.5 & 2 & 3.6 & 49.07 \\
11 & 30 & 5 & 1 & 23 & 30.23 \\
12 & 45 & 3.5 & 0.318 & 4.6 & 17.67 \\
13 & 60 & 2 & 1 & 5.6 & 22.09 \\
14 & 30 & 5 & 3 & 4.0 & 46.51 \\
15 & 60 & 5 & 1 & 10.6 & 28.17 \\
\hline
\end{tabular}

faktor yang terdiri dari konsentrasi enzim, suhu hidrolisis, dan waktu hidrolisis diperlihatkan pada Tabel 3. Data tersebut kemudian diolah dengan perangkat lunak DX versi 10 untuk menentukan kondisi optimum percobaan.

\subsection{Jumlah Lemak}

Jumlah lemak yang diperoleh memiliki variasi sebesar 3,2-23 mg/100 g berat basah rumput laut $C$. lentillifera dengan bantuan enzim dan ekstraksi pelarut organik yaitu diklorometan modifikasi Bligh and Dyer. Pada beberapa studi, kloroform diganti dengan diklorometan sebagai alternatif untuk mengurangi tingkat toksik dari kloroform (Maciel et al., 2016). Jumlah tersebut sangat kecil jika dibandingkan dengan total lemak pada berat kering $C$. lentillifera (freeze dried) yang dapat mencapai rentang 0,86\%-2,87 yang diperoleh dari beberapa negara (Zhang et al., 2020).

Pada beberapa model, DX 10 menyarankan model berdasarkan variabel terikat yang diperoleh yaitu model 2FI yang memiliki nilai $\mathrm{p}$ terkecil yaitu sebesar 0,3412 , namun nilai tersebut lebih besar dari $0,05(\alpha)$, hal tersebut menunjukkan bahwa keterandalan model rendah. (Tabel 4).
Analisis ragam digunakan untuk mengevaluasi kecukupan model dan signifikansi statistik dari faktor-faktor yang digunakan pada model (Pishgar-komleh et al., 2012). Model yang disarankan oleh perangkat kemudian dilakukan analisis ragam. Berdasarkan analisis ragam (Tabel 5), nilai $\mathrm{p}$ yang diperoleh yaitu 0,4666 lebih besar dibanding alpha $(0,05)$ sehingga dapat dinyatakan tidak berbeda nyata. Pada nilai R-square, dihasilkan nilai sebesar 0,4376, nilai tersebut lebih besar dari 0,4 dan lebih kecil dari 0,599 yang menunjukkan tingkat hubungan yang sedang (Sugiyono, 2015). Pada nilai tersebut juga menjelaskan bahwa sekitar 43,76\% jumlah lemak dipengaruhi oleh parameter perlakuan dan lebih dari separuh data rendemen lemak dipengaruhi oleh faktor lain. Hasil tersebut dapat dinyatakan bahwa tidak ada satupun faktor independen yang memengaruhi variabel terikat.

Adapun persamaan yang diperoleh berdasarkan pada model $2 \mathrm{FI}$ variabel terikat Y1 yaitu jumlah lemak yang dihasilkan dipengaruhi oleh faktor-faktor diantaranya konsentrasi enzim (X1), suhu hidrolisis (X2), dan waktu hidrolisis (X3) tertuang pada Persamaan (2). 
Tabel 4. Model yang direkomendasikan untuk jumlah lemak.

Table 4. Recommended model for lipid amount.

\begin{tabular}{lccc}
\hline \multicolumn{1}{c}{ Source } & Sequential p-value & Adjusted R-Squared & Information \\
\hline Linear & 0.5589 & -0.0631 & \\
2FI & 0.3412 & 0.0159 & Suggested \\
Quadratic & 0.8639 & -0.3751 & \\
Cubic & 0.4964 & 0.1836 & Aliased \\
\hline
\end{tabular}

Tabel 5. Analisis sidik ragam jumlah lemak.

Table 5. Analysis of variance of lipid amount.

\begin{tabular}{lccccc}
\hline \multicolumn{1}{c}{ Source } & Sum of Square & Df & Mean square & F-value & $p$-value \\
\hline Model & 156.67 & 6 & 26.11 & 1.04 & 0.4666 \\
X1 & 1.39 & 1 & 139 & 0.055 & 0.8198 \\
X2 & 9.11 & 1 & 9.11 & 0.36 & 0.564 \\
X3 & 48.47 & 1 & 48.47 & 1.93 & 0.2026 \\
X1X2 & 4.5 & 1 & 4.5 & 0.18 & 0.6835 \\
X1X3 & 67.28 & 1 & 67.28 & 67.28 & 0.1407 \\
X2X3 & 25.92 & 1 & 25.92 & 25.92 & 0.3399 \\
Residual & & 8 & & & \\
Cor-total & & 14 & & & \\
$R$-square & 0.4376 & & & & \\
St. Dev & 5.02 & & & & \\
\hline
\end{tabular}

$Y 1=13,89041+4,44452 X 1-0,29130 X 2-$ $6,38384 X 3-0,033333 X 1 X 2+1,20000 X 1 X 3-$ $0,19333 \times 2 X 3$

Kombinasi faktor-faktor tersebut dievaluasi untuk melihat perolehan rendemen lemak. Grafik kontur dan permukaan 3 dimensi dijelaskan pada Gambar 5a yang menjelaskan tentang faktor suhu dan waktu hidrolisis terhadap jumlah lemak yang dihasilkan. Berdasarkan gambar tersebut, peningkatan faktor suhu maupun waktu hidrolisis pada konsentrasi enzim 3,5\% tidak meningkatkan jumlah lemak, cenderung menurun namun tidak signifikan. Pada Gambar 5b mendeskripsikan tentang pengaruh waktu hidrolisis dan konsentrasi enzim pada suhu $30{ }^{\circ} \mathrm{C}$ terhadap jumlah lemak yang dihasilkan. Adapun penambahan konsentrasi enzim memberikan peluang terjadi peningkatan jumlah lemak, namun berbanding terbalik dengan penambahan waktu hidrolisis. Berdasarkan Gambar 5c, dalam waktu 1 jam faktor konsentrasi enzim yang meningkat dapat memungkinkan terjadi peningkatan jumlah lemak, namun berbanding terbalik dengan peningkatan suhu.

Pemilihan faktor independen yaitu suhu, waktu, dan konsentrasi enzim merupakan beberapa faktor yang diduga dapat memengaruhi aktivitas optimal dari suatu enzim untuk meningkatkan jumlah rendemen target dalam suatu sel tanaman. Pada hampir semua penelitian terkait proses ekstraksi komponen dari rumput laut, bentuk sampel yang digunakan adalah dalam bentuk bubuk/kering setelah melalui proses liofilisasi. Berdasarkan hasil penelitian dapat dinyatakan bahwa, penggunaan sampel segar rumput laut dengan kandungan air mencapai 98,28\% (Nguyen et al., 2011) cukup sulit untuk mendeterminasi pengaruh faktor independen terhadap variabel terikat seperti persen rendemen lemak. Penelitian tentang disrupsi sel pada sampel kering beku (freeze-dried) untuk membantu ekstraksi lemak telah dilakukan pada beberapa penelitian seperti Chlorella vulgaris (Orr et 


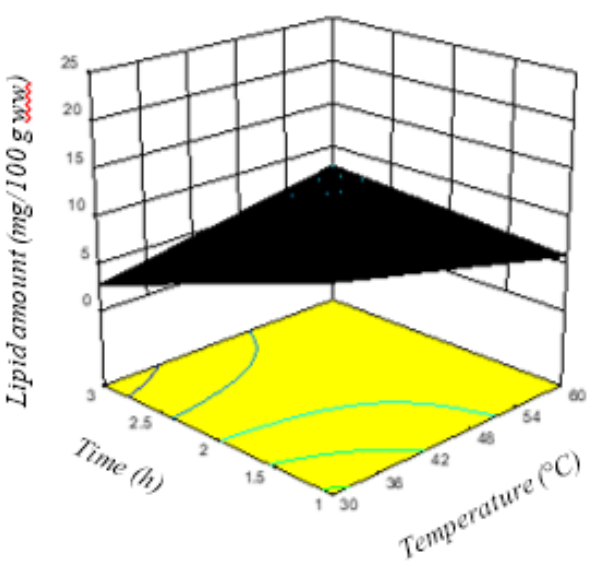

(a)

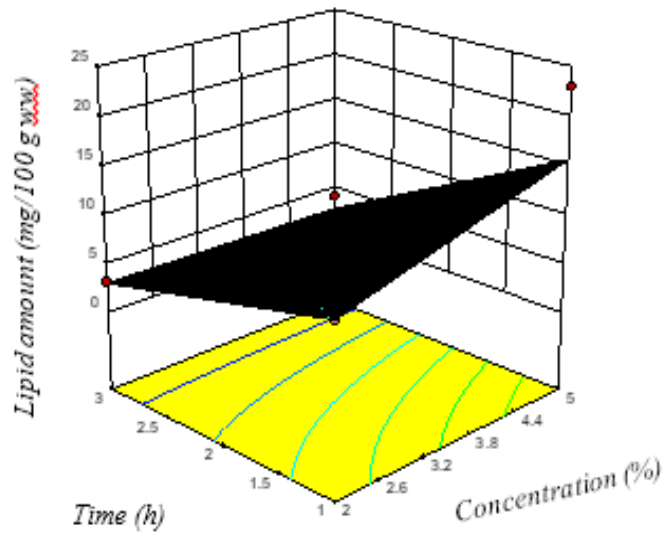

(b)

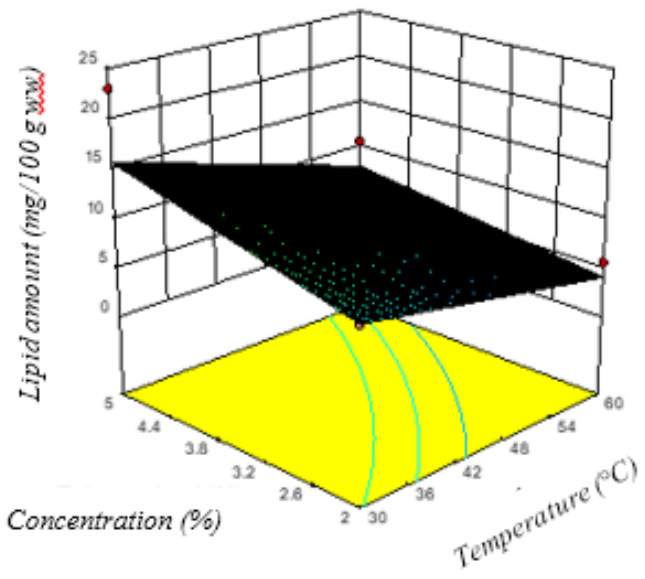

(c)

Gambar 5. Grafik respons permukaan (a) suhu dan waktu (b) konsentrasi enzim dan waktu (c) konsentrasi dan suhu enzim.

Figure 5. Surface response graph (a) temperature and time (b) enzyme concentration and time (c) enzyme concentration and temperature.

al., 2015), Spirulina platensis (Duongbia et al., 2018), Scenedesmus (Lai et al., 2016), Undaria pinnatifida (Billakanti et al., 2013), Enteromorpha prolifera (Michalak et al., 2017), Soliera chordalis dan Sargassum muticum (Terme et al., 2018). Penggunaan bahan tanaman segar yang diekstraksi lemaknya dilakukan pada penelitian Vanhercke et al. (2013) dengan sampel daun Nicotiana tabacum dan penelitian Loneman et al. (2017) dengan sampel rambut jagung. Asam lemak yang diperoleh dari bentuk kering pada jaringan jagung lebih tinggi dibanding dalam bentuk segar dan utuh. Perolehan lemak dari daun $N$. tabacum juga didapatkan dari lemak permukaan (surface lipid).

Secara umum, suhu yang optimum digunakan sebagai penentu karakteristik enzim. Penelitian Almeida \& Maranan (2019) melaporkan suhu optimum tidak konstan pada suatu enzim. Suhu optimum pada enzim beta-glukosidase berubah $5^{\circ} \mathrm{C}$ dengan modifikasi lamanya pengujian. Hal tersebut berkolerasi terbalik dengan konsentrasi enzim. Denaturasi pada enzim 
secara terus menerus akan menurunkan aktivitas enzim saat pengujian. Suhu optimum hampir tidak mencerminkan sifat enzim, sehingga mengadopsi optimum suhu pada lamanya waktu pengujian dan konsentrasi enzim dapat menghasilkan rendemen yang lebih rendah. Namun pada beberapa penelitian terkait enzim selulase, parameter suhu optimum tetap digunakan untuk menentukan aktivitas enzim. Pada penelitian Iqbal et al. (2011) suhu optimum yang dihasilkan yaitu $55{ }^{\circ} \mathrm{C}$, jika melebihi maka aktivitas enzim akan menurun diakibatkan oleh denaturasi protein. Adapun suhu optimum pada penelitian Islam \& Roy (2018) yaitu sebesar $40{ }^{\circ} \mathrm{C}$. Grafik pada Gambar 3 menunjukkan bahwa pada suhu maksimal yaitu $60{ }^{\circ} \mathrm{C}$, jumlah lemak yang dihasilkan semakin sedikit dapat disebabkan karena aktivitas enzim yang menurun. Faktor konsentrasi pada Gambar 3 terlihat bahwa semakin tinggi konsentrasi maka jumlah lemak yang dihasilkan semakin meningkat. Penelitian terkait konsentrasi enzim selulase (Ghazal et al., 2016), konsentrasi yang digunakan adalah $1 \%, 3 \%$, dan 5\%. Adapun pada konsentrasi 3\% menghasilkan ekstrak lemak terbanyak. Pada waktu hidrolisis merupakan waktu kontak antara enzim selulase dan substrat selulosa pada dinding sel rumput laut. Grafik menunjukkan bahwa interaksi waktu hidrolisis cenderung menghasilkan jumlah lemak menurun namun tidak signifikan seiring bertambahnya waktu. Pada penelitian terkait waktu hidrolisis (You et al., 2011), menggunakan waktu hidrolisis 2 jam, 5 jam, dan 8 jam pada enzim karbohidrase. Jumlah lemak yang dihasilkan fluktuatif. Pada waktu 2 jam dan 8 jam dapat menghasilkan jumlah lemak yang sama.

\subsection{Aktivitas Antioksidan}

Analisis aktivitas antioksidan dilakukan dengan menggunakan metode ABTS. Pengujian aktivitas antioksidan dengan radikal ABTS didasarkan pada transfer elektron (Sivaramakrishnan et al., 2017). Konsentrasi penghambatan yang digunakan adalah 100 ppm untuk setiap perlakuan. Pada varibel terikat aktivitas antioksidan, model yang disarankan adalah model linear yang memiliki nilai $\mathrm{p}$ kurang dari $0,05(\alpha)$, hal tersebut menunjukkan bahwa keterandalan cukup tinggi (Tabel 6).

Model linear yang disarankan untuk variabel terikat aktivitas antioksidan kemudian dianalisis menggunakan analisis ragam. Tabel 7 menjelaskan terkait analisis ragam pada aktivitas antioksidan. Adapun nilai-p pada tabel tersebut yaitu sebesar 0,0294, nilai tersebut menunjukkan hasil yang signifikan karena $\mathrm{p}>0,05$ sebagai alpha, terutama pada faktor waktu yang meiliki nila-p sebesar 0,005. Sehingga dapat dinyatakan bahwa, aktivitas antioksidan berbeda nyata karena dipengaruhi oleh faktor waktu. Nilai R-square atau koefisien determinasi yang dihasilkan yaitu 0,5442 . Nilai tersebut lebih besar dari 0,5 namun kurang dari 0,599 sehingga tingkat hubungannya dapat dinyatakan sedang (Sugiyono, 2015). Pada nilai tersebut juga menjelaskan $54,42 \%$ dipengaruhi oleh faktor independen terkait, sedangkan persentase lainnya dipengaruhi oleh faktor luar. Hal tersebut menunjukkan $<50 \%$ variabel terikat dipengaruhi oleh faktor lain.

Tabel 6. Model yang direkomendasikan untuk aktivitas antioksidan.

Table 6. Recommended model for antioxidant activity.

\begin{tabular}{lccc}
\hline \multicolumn{1}{c}{ Source } & Sequential p-value & Adjusted $R$-Squared & Information \\
\hline Linear & 0.0294 & 0.4198 & Suggested \\
2FI & 0.3909 & 0.4407 & \\
Quadratic & 0.2592 & 0.5732 & \\
Cubic & 0.6241 & 0.5764 & Aliased \\
\hline
\end{tabular}


Tabel 7. Analisis sidik ragam aktivitas antioksidan.

Table 7. ANOVA of antioxidant activity.

\begin{tabular}{lccccc}
\hline \multicolumn{1}{c}{ Source } & Sum of Square & Df & Mean square & F-value & p-value \\
\hline Model & 156.67 & 3 & 534.24 & 4.38 & 0.029 \\
X1 & 1.39 & 1 & 165.62 & 1.36 & 0.269 \\
X2 & 9.11 & 1 & 0.016 & 1.306 & 0.99 \\
X3 & 48.47 & 1 & 1437.1 & 11.77 & 0.005 \\
Residual & 1342.6 & 11 & 122.1 & & \\
Cor total & 2945.3 & 14 & & & \\
$R$-square & 0.5442 & & & & \\
St. Dev & 11.05 & & & & \\
\hline
\end{tabular}

Persamaan yang diperoleh dari model linear dengan keterangan X1 konsentrasi enzim, X2 suhu hidrolisis dan X3 waktu sebagai faktor dan $\mathrm{Y}$ adalah aktivitas antioksidan dijabarkan pada Persamaan (3):

\section{$Y 2=27,49751+0,022776 X 1-$ $0,23216 X 2+10,25809 X 3$}

Tidak dilihat interaksi antar faktor independen pada model linear, $t$. Berdasarkan Tabel 8, setiap faktor dilihat pengaruhnya masing-masing terhadap variabel terikat. Faktor tersebut diantaranya suhu hidrolisis, konsentrasi enzim dan waktu hidrolisis. Pada Gambar 6a menjelaskan konsentrasi enzim terhadap aktivitas antioksidan dalam bentuk persentase penghambatan radikal ABTS. Peningkatan konsentrasi enzim tidak meningkatkan aktivitas antioksidan namun cenderung konstan, sedangkan pada Gambar 6b menjelaskan grafik tentang pengaruh faktor suhu terhadap aktivitas antioksidan. Peningkatan suhu terlihat menurunkan penghambatan ekstrak terhadap radikal. Pengaruh faktor waktu terhadap aktivitas antioksidan dijelaskan pada Gambar 6c. Pada grafik tersebut menunjukkan bahwa, kenaikan waktu dapat meningkatkan aktivitas antioksidan pada konsentrasi 100 ppm.

Berdasarkan pada pengaruh faktor pada Gambar 6, suhu hidrolisis dan waktu hidrolisis memperlihatkan penurunan dan kenaikan pada aktivitas antioksidan. Menurut Sivaramakrishnan et al. (2017) pada konsentrasi ekstrak yang rendah cukup untuk membatalkan mediasi reaksi berantai dari radikal bebas, sehingga pengaruhnya cenderung konstan. Komponen antioksidan pada semua studi dapat menurun seiring dengan peningkatan suhu, namun laju penurunannya berbeda-beda (Réblová, 2012). Aktivitas antioksidan pada rumput laut telah ditemukan dari berbagai komponen seperti polisakarida, serat makanan, mineral, protein, asam amino, vitamin, polifenol dan karotenoid. Rumput laut menghasilkan berbagai jenis antioksidan untuk mengatasi tekanan lingkungan (Boonchum et al., 2011). Karakteristik dan aktivitas antioksidan pada ekstrak dari rumput laut segar dipengaruhi oleh pelarut yang digunakan. Aktivitas radikal ABTS digunakan untuk menentukan kapasitas antioksidan hidrofilik maupun hidrofobik (Yarnpakdee et al., 2018). Pelarut yang digunakan pada penelitian ini adalah diklorometan yang tergolong ke dalam pelarut non polar, maka komponen yang terekstrak dapat memiliki sifat hidrofobik. Ekstrak diklorometan dari rumput laut cokelat Padina tetrastomatica (Chandini et al., 2008) memiliki aktivitas antioksidan mencapai $14,23 \%$ dengan metode DPPH, sedangkan rumput laut merah Euchema kappaphycus hanya mencapai $6,41 \%$ (Ganesan et al., 2008). 


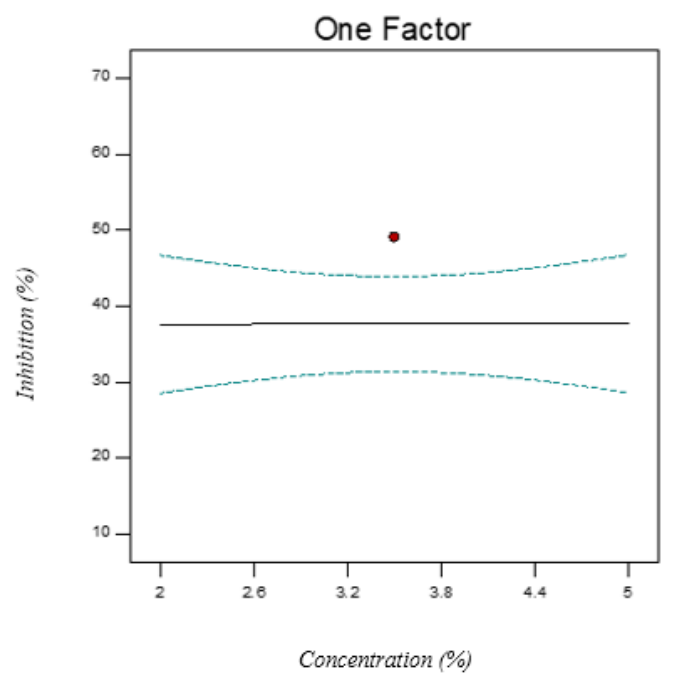

(a)

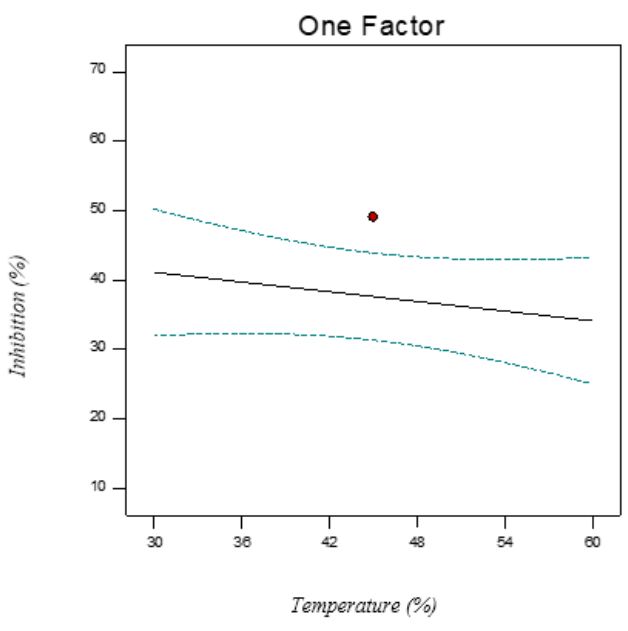

(b)

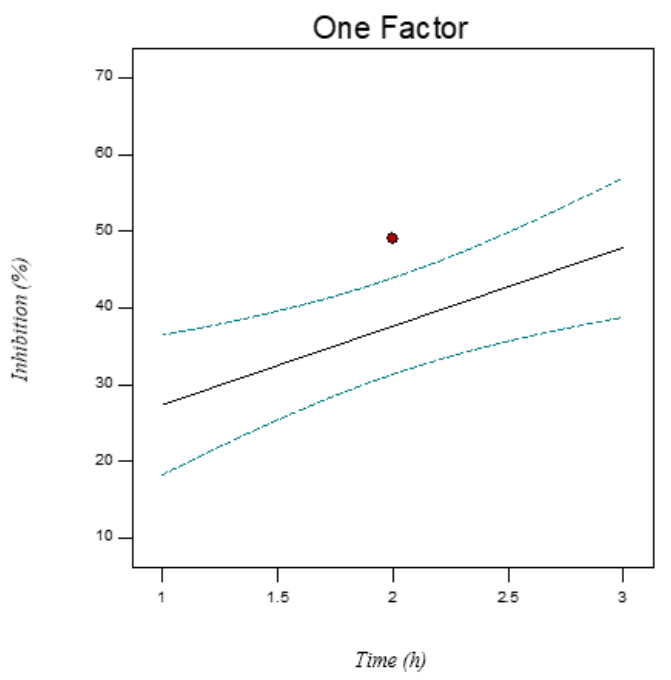

(c)

Gambar 6. Grafik satu faktor (a) konsentrasi enzim (b) suhu hidrolisis (c) waktu hidrolisis.

Figure 6. One factor graph (a) enzyme concentration (b) hydrolysis temperature (c) hydrolysis time.

\subsection{Hasil Optimasi}

Data yang didapatkan untuk kedua respons tidak tersedia lack of fit. Menurut Rheem et al. (2017), ketika model terhadap data memiliki lack of fit yang buruk atau tidak memiliki lack of fit, hasil pemodelan dan optimasi mungkin tidak akurat. Nilai lack of fit memiliki derajat bebas sebesar 0 (nol). Hal tersebut dapat disebabkan karena bentuk sampel yang digunakan berbentuk segar. Pada beberapa penelitian, sampel yang digunakan berbentuk kering beku (freeze-dried). Secara umum, prosedur ekstraksi lemak dari jaringan tumbuhan memiliki beberapa langkah yaitu perlakuan awal sampel seperti pengeringan, pengecilan ukuran dan hidrolisis, homogenisasi jaringan dengan pelarut, pemisahan cairan dan fase padat, penghilangan kontaminan nonlemak, penguapan pelarut dan pengeringan ekstrak (Shahidi \& Wanasundara, 2008). Pada data tersebut dilanjutkan ke tahap optimasi 
Tabel 8. Prediksi variabel independen.

Table 8. Independen variable prediction.

\begin{tabular}{lcccc}
\hline \multicolumn{3}{c}{ Optimum prediction condition } & \multicolumn{2}{c}{ Prediction value } \\
\hline Temp. & Enzyme conc. & Time & Lipid amounts & Antioxidant activity \\
\hline $30{ }^{\circ} \mathrm{C}$ & $2 \%$ & $1 \mathrm{~h}$ & $9.05657 \mathrm{mg}$ & $30.8362 \%$ \\
\hline
\end{tabular}

Tabel 9. Hasil identifikasi asam lemak.

Table 9. Fatty acid identification result.

\begin{tabular}{cccccc}
\hline \multicolumn{3}{c}{ Optimum condition } & \multirow{2}{*}{ RT (min) } & \% Area & \multirow{2}{*}{ Fatty acid } \\
\cline { 1 - 2 } Temp. & Enzyme conc. & Time & & & \\
\cline { 1 - 2 } $30{ }^{\circ} \mathrm{C}$ & \multirow{2}{*}{$2 \%$} & $1 \mathrm{~h}$ & 30.98 & 0.01 & Palmitic acid \\
& & & 61.36 & 0.01 & Lauric acid \\
\hline
\end{tabular}

melalui perangkat lunak.

Kondisi optimum pada suatu rancangan percobaan ditentukan berdasarkan kriteria setiap faktor yang diinginkan. Pada setiap faktor yaitu suhu hidrolisis, konsentrasi enzim, dan waktu hidrolisis yang diinginkan adalah minimal. Solusi yang diberikan oleh perangkat lunak DX 10 yaitu pada suhu hidrolisis sebesar $30{ }^{\circ} \mathrm{C}$, pada konsentrasi enzim sebesar $2 \%$ dan pada waktu hidrolisis adalah 1 jam (Tabel 8). Pada kondisi tersebut diprediksi jumlah lemak yang dihasilkan adalah $9,057 \mathrm{mg}$ dan aktivitas penghambatan yaitu 30,836\%. Kondisi optimum tersebut kemudian dapat diverifikasi dengan melakukan perlakuan terpilih sebanyak 2 kali ulangan atau lebih, hingga mendekati hasil prediksi. Kriteria suhu, konsentrasi, dan waktu minimize, sedangkan jumlah lemak dan aktivitas antioksidan in range.

\subsection{Profil Asam Lemak}

Identifikasi asam lemak yang terkandung di dalam ekstrak lemak rumput laut sebelumnya dikonversi terlebih dahulu menjadi FAME, kemudian disaring dengan filter Millipore $0,45 \mu \mathrm{m}$ dan dimasukkan ke dalam vial kecil. Sampel diinjeksikan ke dalam GC/MS-QP2010 Ultra. Berdasarkan Tabel 9, asam lemak pada $C$. lentillifera dari Jepara yang terdeteksi yaitu asam palmitat atau C16:0 dan asam laurat atau C12:0. Pada penelitian dengan sampel $C$. lentillifera kering dari Kalimantan Timur dengan pelarut dietil eter, asam palmitat atau C16:0 merupakan asam lemak jenuh yang melimpah yaitu mencapai $33,78 \%$ setelah asam lemak oleat atau omega 9 (Matanjun \& Muhammad, 2010).

\section{KESIMPULAN}

Kondisi optimum yang diperoleh yaitu suhu hidrolisis sebesar $30{ }^{\circ} \mathrm{C}$, pada konsentrasi enzim sebesar $2 \%$ dan pada waktu hidrolisis adalah 1 jam. Asam lemak yang diperoleh mengandung asam palmitat dan asam laurat. Optimasi proses ekstraksi lemak memungkinkan potensi pemanfaatan lemak dari rumput laut segar $C$. lentillifera dengan metode yang efektif berdasarkan suhu hidrolisis, konsentrasi enzim dan waktu hidrolisis yang dibutuhkan. Hal ini akan berdampak pada efisiensi biaya ekstraksi lemak pada rumput laut.

\section{UCAPAN TERIMA KASIH}

Ucapan terima kasih kepada Kementerian Riset dan Teknologi Pendidikan Tinggi melalui pendanaan Insentif Riset Sistem Inovasi Nasional (INSINAS) gelombang 2 tahun anggaran 2019. Pendanaan tersebut telah berkontribusi besar pada kelancaran penelitian ini. 


\section{DAFTAR PUSTAKA}

Ait-Amir, B., P. Pougnet, \& A.E. Hami. 2015. Meta-model development. Embedded Mechatronic Systems 2. Elsevier. Amsterdam. 158 pp.

Almeida, V.M. \& S.R. Marana. 2019. Optimum temperature may be a misleading parameter in enzyme characterization and application. Plos ONE, 14(2): 1-8.

https://doi.org/10.1371/journal.pone.0 212977

Anne-sophie, B., B. Gilles, \& B. Nathalie. 2016. Response surface methodology for enzyme-assisted extraction of water- soluble antiviral compounds from the proliferative macroalga Solieria chordalis. Enzyme Engineering, 5(2): 1-8. https://doi.org/10.4172/2329-6674.10 00148

Billakanti, J.M., O.J. Catchpole, T.A. Fenton, K.A. Mitchell, \& A.D. MacKenzie. 2013. Enzyme-assisted extraction of fucoxanthin and lipids containing polyunsaturated fatty acids from Undaria pinnatifida using dimethyl ether and ethanol. Process biochemistry, 48(12): 1999-2008. https://doi.org/10.1016/j.procbio.201 3.09.015

Boonchum, W., Y. Peerapornpisal, D. Kanjanapothi, J. Pekkoh, C. Pumas, U. Jamjai, \& P. Vacharapiyasophon. 2011. Antioxidant activity of some seaweed from the Gulf of Thailand. International J. of Agriculture \& Biology, 13(1): 95-99.

https://www.fspublishers.org/publish ed_papers/67335_..pdf

Chandini, S.K., P. Ganesan, \& N. Bhaskar. 2008. Food chemistry in vitro antioxidant activities of three selected brown seaweeds of India. Food Chemistry, 107: 707-713.

https://doi.org/10.1016/j.foodchem.20 07.08.081
Dahlia, I., S. Rejeki, \& T. Susilowati. 2015. Pengaruh dosis pupuk dan substrat yang berbeda terhadap pertumbuhan Caulerpa lentillifera. J. of Aquaculture Management and Technology, 4(4): 28-34. https://ejournal3.undip.ac.id/index.ph p/jamt/article/view/9802

Dangeubun, J.L. \& E.M.Y. Kadmaer. 2018. Penerapan iptek di Desa Wab Ngufar untuk manajemen budidaya makroalga hijau Caulerpa racemosa dan Caulerpa lentillifera "LAT". Majalah Aplikasi Ipteks Ngayah, 9(2): 246-258.

https://e-journal.unmas.ac.id/index.ph p/ngayah/article/view/200

Deslandes, E., V. Stiger-Pouvreau, \& N. Bourgougnon. 2016. Carbohydrates from seaweeds. In: Fluerence, J. and I. Levine (eds.). Seaweed in health and disease prevention. Academic Press. Cambridge. 255 pp.

Duongbia, N., S. Chaiwongsar, C. Chaichana, \& S. Chaiklangmuag. 2018. Acidic hydrolysis performance and hydrolyzed lipid characterizations of wet Spirulina platensis. Biomas Conversion and Biorefinery, 9: 305-319. https://doi.org/10.1007/s13399-018-0 350-6

Dutka, M., M. Ditaranto, \& T. Lovas. 2015. Application of a central composite design for the study of NOx emission performance of a low NOx burner. Energies, 8(5): 3606-3627. https://doi.org/10.3390/en8053606

Fiset, C., J. Liefer, A.J. Irwin, \& Z.V. Finkel. 2017. Methodological biases in estimates of macroalgal macromolecular composition. Limnology and Oceanography, 15: 618-630.

https://doi.org/10.1002/lom3.10186

Fitriana, W.D., S. Fatmawati, \& T. Ersam. 2015. Uji aktivitas antioksidan terhadap DPPH dan ABTS dari 
fraksi-fraksi daun kelor (Moringa oleifera). Prosiding Simposium Nasional dan Pembelajaran Sains, 8 dan 9 Juni 2015. 657-660 hlm.

Ganesan, P., C.S. Kumar, \& N. Bhaskar. 2008. Antioxidant properties of methanol extract and its solvent fractions obtained from selected indian red seaweeds. Bioresource Technology, 99: 2717-2723.

https://doi.org/10.1016/j.biortech.200 7.07.005

Gao, Y., M. Yang, \& C. Wang. 2013. Bioresource technology nutrient deprivation enhances lipid content in marine microalgae. Bioresource Technology, 147: 484-491. https://doi.org/10.1016/j.biortech.201 3.08 .066

Ghazal, M.A., H.A.H Ibrahim, N.A. Shaltout, \& A.E. Ali. 2016. Biodiesel and bioethanol production from Ulva fasciata delie biomass via enzymatic pretreatment using marine-derived Aspergillus niger. Int. J. Pure App. Bioscience, 4(5): 1-16.

https://doi.org/10.18782/2320-7051.2 374

Puspitasari, G., W. A. Safrihatini, \& K. Umam. 2019. Studi kinetika reaksi dari enzim $\alpha$-amilase pada proses penghilangan kanji kain kapas. Arena Tekstil, 34(1): 1-6.

https://doi.org/10.31266/at.v34i1.509 10427

Ginneken, V.J.T. van, J.P.F.G. Helsper, W. de Visser, H. van Keulen, \& W.A. Brandenburg. 2011. Polyunsaturated fatty acids in various macroalgal species from north atlantic and tropical seas. Lipids in Health and Disease, 10(1): 104-112. https://doi.org/10.1186/1476-511X-1 0-104

Guerra, N.P. 2017. Enzyme kinetics experiment with the multienzyme complex viscozyme $\mathrm{L}$ and two substrates for the accurate determination of michaelian parameters. J. Chem. Educ., 94(6): 795-799.

https://doi.org/10.1021/acs.jchemed.6 b00351

Haryanto, M.G., S. Setyahadi, M. Sahlan, M. Yohda, Y. Fukutani, E.A. Suryono, \& Misri. 2018. Characterization of cellulase from E. coli BPPTCC-EGRK2. Consortium Studies of Smallholder Palm Oil International Conference, Sarawak, Malaysia, 9 Juli-11 Juli 2018. 1660-1666 pp.

https://doi.org/10.1051/e3sconf/2018 5200024

Iqbal, H.M.N., I. Ahmed, M.A. Zia, \& M. Irfan. 2011. Purification and characterization of the kinetic parameters of cellulase produced from wheat straw by Trichoderma viride under SSF and its detergent compatibility. Advances in Bioscience and Biotechnology, 2 (3): 149-156.

https://doi.org/10.4236/abb.2011.230 24

Islam, F. \& N. Roy. 2018. Screening, purification and characterization of cellulase from cellulase producing bacteria in molasses. BMC Research Notes, 11(1): 1-6. https://doi.org/10.1186/s13104-018-3 558-4

Iwundu, M.P. 2018. Construction of modified central composite design for non-standard models. Int. J. of Statistics and Probability, 7(5): 95-119. https://doi.org/10.5539/ijsp.v7n5p95

Kementrian Kelautan dan Perikanan (KKP). 2019. Pedoman umum pembudidayaan rumput laut. Nomor 1/KEPMEN-KP/2019. KKP. Jakarta. 4-5 hlm.

Lai, Y.J.S., F. De Francesco, A. Aguinaga, P. Parameswaran, \& B.E. Rittmann. 2016. Improving lipid recovery from 
Scenedesmus wet biomass by surfactant-assisted disruption. Green Chemistry, 18(5): 1319-1326. https://doi.org/10.1039/C5GC02159F

Liang, K., Q. Zhang, \& W. Cong. 2012. Enzyme-assisted aqueous extraction of lipid from microalgae. $J$. of Agricultural and Food Chemistry, 60(47): 11771-11776. https://doi.org/10.1021/jf302836v

Lin, Y., X. Xie, B. Yuan, J. Fu, L. Liu, H. Tian, \& D. He. 2018. Optimization of enzymatic cell disruption for improving lipid extraction from Schizochytrium sp. through response surface methodology. J. of Oleo Science, 67(2): 215-224. https://doi.org/10.5650/jos.ess17166

Lone, M.A., S. Sahay, R. Rana, M.A. Rather, F.A. Dar, F.A. Maila, \& M.A. Reshi. 2014. Kinetic determining innovations of carboxymethyl cellulase enzyme isolated from Trichophyton terrestre in carboxymethyl cellulose solution. Discovery J., 24(84):110-117. https://www.discoveryjournals.org/di scovery/current_issue/v24/n80-85/A1 6.pdf?

Loneman, D.M., L. Peddicord, A. Al-rashid, J. Nikolau, N. Lauter, \& M.D. Yandaeau-Nelson. 2017. A robust and efficient method for the extraction of plant extracellular surface lipids as applied to the analysis of silks and seedling leaves of maize. Plos ONE, 12(7): 1-21. https://doi.org/10.1371/journal.pone.0 180850

Maciel, E., M.C. Leal, A.I. Lilleb $\varnothing$, P. Domingues, M.R. Domingues, \& R. Calado. 2016. Bioprospecting of marine macrophytes using ms-based lipidomics as a new approach. Marine Drugs, 14(49): 1-28. https://doi.org/10.3390/md14030049

Maftukhah, S. \& Abdullah. 2018. Cellulase enzyme production from rice straw using solid state fermentation and fungi Aspergillus niger ITBCC L74. The 24th Regional Symposium on Chemical Engineering, Semarang, Indonesia, 15-16 November 2017. 1-7 pp. https://doi.org/10.1051/matecconf/20 1815601010

Matanjun, P. \& K. Muhammad. 2010. Comparison of cardiovascular protective effect of tropical seaweeds, Kappaphycus alvarezii, Caulerpa lentillifera, and Sargassum polycystum on High-Cholesterol/High-Fat Diet in Rats. J. of Medicinal Food, 13(4): $1-10$.

https://doi.org/10.1089/jmf.2008.121 2

Michalak, I., A. Dmytryk, A. Smieszek, \& K. Marycz. 2017. Chemical characterizaton of Enteromorpha prolifera extract obtained by enzyme-assisted extrction an its influence on the metabolic activity of Caco-2. International J. of Molecular Science 18(3): 1-20. https://doi.org/10.3390/ijms18030479

Mubarak, M., A. Shaija, \& T.V. Suchithra. 2016. Optimization of lipid extraction from Salvinia molesta for biodiesel production using RSM and its FAME Analysis. Environmental Science and Pollution Research, 23: 14047-14055. https://doi.org/10.1007/s11356-016-6 343-8

Nguyen, V.T., J.P. Ueng, \& G.J. Tsai. 2011. Proximate composition, total phenolic content, and antioxidant activity of seagrape (Caulerpa lentillifera). J. of Food Science, 76(7): 950-958. https://doi.org/10.1111/j.1750-3841.2 011.02289.x

Orr, V.C.A., N.V. Plechkova, K.R. Seddon, \& L. Rehmann. 2015. Disruption and wet extraction of the microalgae 
chlorella vulgaris using room-temperature ionic liquids. ACS Sustainable Chemistry and Engineering, 4(2): 591-600.

https://doi.org/10.1021/acssuschemen g.5b00967

Peraturan Presiden (Perpres). 2019. Peta Panduan (Road Map) Pengembangan industri rumput laut nasional tahun 2018-2021. Peraturan Presiden Republik Indonesia Nomor 33 Tahun 2019, Indonesia.

Pishgar-komleh, S., A. Keyhani, M. Mostofi-Sarkari, \& A. Jafari. 2012. Application of response surface methodology for optimization of picker- husker harvesting losses in corn seed. Iranica J. of Energy \& Environment, 3(2): 134-142. https://doi.org/10.5829/idosi.ijee.201 2.03.02.0027

Prakoso, F.D., F. Lestari, \& T. Apriadi. 2019. Jenis dan sebaran makroalga di perairan Pulau Beralas Bakau Kecematan Gunung Kijang Kabupaten Bintan. J. Perikanan dan Kelautan, 9(2): 235-245. https://doi.org/10.33512/jpk.v9i2.735 7

Ranade, S.S. \& P. Thiagarajan. 2017. Selection of a design for response surface. Material Science and Engineering, 263(2): 022043. https://doi.org/10.1088/1757-899X/2 63/2/022043

Razai, T.S., I.P. Putra., F. Idris, T. Febrianto, M. Firdaus. 2019. Identifikasi, keragaman, dan sebaran Caulerpa sp. sebagai komoditas potensial budidaya Pulau Bunguran, Natuna. Simbiosam, 8(2): 168-178.

https://doi.org/10.33373/sim-bio.v8i2 .2177

Réblová, Z. 2012. Effect of Temperature on the antioxidant activity of phenolic acids. Czech J. Food Sci., 30(2): 171-177. https://doi.org/10.17221/57/2011-CJF
$\mathrm{S}$

Reddy, A. \& A.B. Majumder. 2014. Use of a Combined technology of ultrasonication, three-phase partitioning, and aqueous enzymatic oil extraction for the extraction of oil from Spirogyra sp. J. of Engineering Hindawi, 2014(2): 1-6. https://doi.org/http://doi.org/10.1155/ 2014/740631

Rheem, S., I. Rheem, \& S. Oh. 2017. Response surface methodology using a fullest balanced model: a re-analysis of a dataset in the korean journal for food science of animal resources. Korean J. for Food Science of Animal Resources, 37(1): 139-146. https://doi.org/10.5851/kosfa.2017.37 .1 .139

Sanjeewa, K.K.A., W. Lee, \& Y. Jeon. 2018. Nutrients and bioactive potentials of edible green and red seaweed in korea. Fisheries and Aquatic Sciences, 21(19): 1-11.

https://doi.org/10.1186/s41240-018-0 095-y

Saropah, D.A., A. Jannah, \& A. Maunatin. 2012. Kinetika reaksi enzimatis ekstrak kasar enzim selulase bakteri selulolitik hasil isolasi dari bekatul. Alchemy, 2(1): 35-45. https://doi.org/10.18860/al.v0i0.2297

Shahidi, F. \& P. Wanasundara. 2008. Food Lipids. Third Edition. CRC Press. 126-127 pp.

Sivaramakrishnan, T., S. Swain, K.R.K.S. Saravanan, S.D. Roy, L. Biswas, \& B. Shalini. 2017. In vitro antioxidant and free radical scavenging activity and chemometric approach to reveal their variability in green macroalgae from south andaman coast of india. Turkish J. of Fisheries and Aquatic Sciences, 17: 639-648. https://doi.org/10.4194/1303-2712-v1 7_3_20

Sugiyono. 2015. Metode Penelitian 
Manajemen (Edisi Keempat). Alfabeta. Bandung. 51 p.

Supriadi, S., R. Syamsuddin, A. Abustang, \& I. Yasir. 2016. Pertumbuhan dan kandungan karotenoid lawi-lawi Caulerpa racemosa yang ditumbuhkan pada tipe substrat berbeda. J. Rumput Laut Indonesia, 1(2): 117-122.

https://journal.indoseaweedconsortiu m.or.id/index.php/jrli/article/view/28/ 25

Synytsya, A., W.J. Kim, \& Y.I. Park. 2015. Cell wall polysaccharides of marine algae. Marine Alga Biotechnology. Springer. Berlin. 543 p. https://doi.org/10.1007/978-3-642-53 971-8

Terme, N., R. Boulho, J.P. Kucma, N. Bourgougnoun, \& G. Bedoux. 2018. Radical scavenging activity of lipids from seaweeds isolated by solid-liquid extraction and supercritica fluids. Oilseeds and fats crops and lipids, 25(5): 1-6. https://doi.org/10.1051/oc1/2018054

Vanhercke, T., A.E. Tahchy, Q. Liu, \& J.R. Petrie. 2014. Metabolic engineering of biomass for high energy density: oilseed-like triacylglycerol yields from plant leaves. Plant Biotechnology J., 12(2): 231-239. https://doi.org/10.1111/pbi.12131

Wijesinghe, W.A.J.P. \& Y. Jeon. 2012. Enzyme-assistant extraction (EAE) of bioactive components: a useful approach for recovery of industrially important metabolites from seaweeds: A review. Fitoterapia, 83(1): 6-12. https://doi.org/10.1016/j.fitote.2011.1 0.016

Yarnpakdee, S., S. Benjakul, \& T. Senphan. 2018. Antioxidant activity of the extracts from freshwater macroalgae
(Cladophora glomerata) grown in northern thailand and its preventive effect against lipid oxidation of refrigerated eastern little tuna slice. Turkish J. of Fisheries and Aquatic Sciences, 19(3): 209-219. https://doi.org/10.4194/1303-2712-v1 9_3_04

Yingyao, W., W. Zhang, C. Shangwei, \& H. Fei. 2008. Aqueous enzymatic extraction of oil and protein hydrolysates from peanut. Food Sci. Technol. Res., 14(6): 533-540. https://doi.org/10.3136/fstr.14.533

Yogyaswari, S.A., M.G.I. Rukmi, \& B. Raharjo. 2016. Eksplorasi bakteri selulolitik dari cairan rumen sapi peranakan fries holland $(\mathrm{PFH})$ dan limousine peranakan ongole (limpo). J. Biologi, 5(4): 70-80. https://ejournal3.undip.ac.id/index.ph $\mathrm{p} /$ biologi/article/view/19516/18508

You, J., C. Peng, X. Liu, X. Ji, J. Lu, Q. Tong, \& Z. Li. 2011. Bioresource technology enzymatic hydrolysis and extraction of arachidonic acid rich lipids from Mortierella alpina. Bioresource Technology, 102(10): 6088-6094.

https://doi.org/10.1016/j.biortech.201 1.01.074

Zhang, M., Y. Ma, X. Che, Z. Huang, P. Chen, G. Xia, \& M. Zhao. 2020. Comparative analysis of nutrient composition of Caulerpa lentillifera from different regions. J. Ocean Univ. China, 19(2): 1-7. https://doi.org/10.1007/s11802-020-4 222-x

Received : 11 November 2020

Reviewed : 07 December 2020

Accepted : 15 February 2021 
